\title{
POLAK SZWEDZKIEGO POCHODZENIA I SZWED W JEDNEJ CZWARTEJ ANDRZEJ NILS UGGLA (1940-2011)
}

W wielu ośrodkach naukowych na świecie pracują naukowcy, których zainteresowania badawcze związane są z historią i kulturą polską. Jednym z nich, był zmarły w Uppsali po długiej chorobie, wybitny slawista, profesor Andrzej Nils Uggla. Mówił o sobie, że jest $w$ jednej czwartej Szwedem. Pochodził ze starej rodziny szwedzkiej, której przedstawiciele osiedlili się w Królestwie Polskim w XIX w. Rodzina utrzymywała pamięć o pochodzeniu nadając potomkom szwedzkie imiona i kultywowała związki z kościołem luterańskim.

Ojciec Andrzeja Uggli, prof. Hjalmar Fryderyk Uggla (1908-1983), był znanym gleboznawcą, autorem wielu publikacji naukowych i podręczników akademickich z tej dziedziny. W czasie wojny brał czynny udział w ruchu oporu jako członek Związku Walki Zbrojnej a następnie Armii Krajowej o pseudonimie „Sowa”. Dokumenty poświadczające szwedzkie pochodzenie oraz doskonała znajomość języka niemieckiego przydały mu się w ratowaniu działaczy podziemia. W 1944 r., po upadku powstania warszawskiego ukrywał w swoim domu w Milanówku uciekinierów ze stolicy. Zdarzyło się, że w tym samym momencie przebywało pod jego opieką aż pięćdziesiąt osób. Staraniem Kazimierza Lewartowicza, w czasie wojny czternastolatka, w 2007 r. prof. H. Uggla pośmiertnie i jego małżonka zostali uhonorowani medalem Sprawiedliwi wśród Narodów Świata za ukrywanie Żydów w czasie wojny. Po wojnie Hjalmar Uggla osiadł w Olsztynie, gdzie zaangażował się w powstanie Wyższej Szkoły Rolniczej, której był w późniejszym okresie prorektorem.

Andrzej Nils urodził się w 1940 r. w Warszawie, a wychował w Olsztynie. Na miejsce dalszej nauki wybrał Gdańsk, gdzie studiował filologię polską w Wyższej Szkole Pedagogicznej, poprzedniczce dzisiejszego uniwersytetu. Jego praca magisterska, napisana na seminarium prof. Marii Janion, dotyczyła Przybyszewskiego i Strindberga. Od tej pory związki kulturalne polsko-skandynawskie stały się najważniejszym obszarem zainteresowań badawczych, którym pozostał wierny do końca życia. Ukończenie studiów w 1966 r. zbiegło się z zaproszeniem rodziny Ugglów do Szwecji. Już jako dziecko Andrzej Nils przebywał przez rok w Szwecji, lecz było to zbyt krótko, aby utrwalić znajomość języka szwedzkiego. Związek Rodziny Uggla ufundował mu niewielkie stypendium, dzięki któremu podjął dalsze studia. Naukę łączył z pracą zarobkową, gdyż wsparcie finansowe rodziny było ważne, lecz niewystarczające. Jak pisze Michał Haykowski, skarżył się wówczas, że powinien się raczej uczyć hiszpańskiego niż szwedzkiego, gdyż bardziej mu się to przyda w kuchni restauracyjnej, gdzie dorabiał.

W 1977 r. A. N. Uggla otrzymał stopień doktora filozofii na Wydziale Historii Literatury Uniwersytetu w Uppsali i podjął pracę na Wydziale Slawistyki przy tym samym uniwersytecie. Pracę doktorską Strindberg och den polska teatern 1890-1970: en studie i reception opublikował w 1977 w Uppsali. (Praca ta pt. Strindberg a teatr polski 1890-1970 ukazała się w tłumaczeniu Ewy Gruszczyńskiej w ramach serii „Badania Polonistyczne za Granicą” w 2000 r.) Pierwsze publikacje A. N. Uggli pozosta- 
wały w kręgu zainteresowań związkami polsko-szwedzkimi. Dotyczyły takich zagadnień, jak stosunek szwedzkich poetów do spraw polskich, stosunku Szwecji do powstania warszawskiego, paralela polskiego i szwedzkiego życia teatralnego. Były to zarówno artykuły naukowe, jak i popularyzatorskie, które publikował w szwedzkich periodykach: „Upsala Nya Tidning”, „Folket i Bild”, „Slovo” oraz prasie polskiej: „Życiu Literackim”, „Teatrze”, „Studia Scandinavica” wydawanych przez katedrę Skandynawistyki Uniwersytetu Gdańskiego. Ukoronowaniem tego okresu w działalności naukowej stały się dwie publikacje wydane w 1986 r. Pierwszą był zarys bibliograficzny Polen i svensk press under andra världskriget. En bibliografi (Polska w prasie szwedzkiej w latach II wojny światowej. Bibliografia) oraz monografia: Den svenska polenbilden och polsk prosa i Sverige 1939-1960. Två studier i reception (Obraz Polski i prozy polskiej w Szwecji w latach 1939-1960. Dwa studia z recepcji). Ta ostatnia pozycja jest próbą odpowiedzi na pytanie, w jaki sposób Szwedzi zapoznawali się $\mathrm{z}$ literaturą polską $\mathrm{w}$ okresie wojny i pierwszym, powojennym piętnastoleciu? Jest to studium z pogranicza literatury, historii i socjologii.

W kolejnych latach kontynuował badania nad polsko-szwedzkimi związkami literackimi i problemami recepcji polskiej poezji i prozy w Szwecji. Zaowocowały one dwiema książkami, które ukazały się w serii „Uppsala Slavonic Papers”. Obie były poświęcone trudnościom, jakie napotykała polska literatura w Szwecji w XIX i XX wieku. Pierwsza wydana w 1989 r. pt. Från politik till litteratur: Sveriges väg till den polska nationella diktningen under 1800-talet i sju studier (Od polityki do literatury. Szwedzka droga ku literaturze polskiej w XIX wieku. Siedem studiów). Druga, wydana w 1990 r., poświęcona została recepcji poezji polskiej w Szwecji: Sverige och polska skalder. Från Mickiewicz till Miłosz (Szwecja a polscy poeci. Od Mickiewicza do Miłosza). Podsumowaniem badań nad obecnością literatury polskiej w Szwecji stała się, wydana w Gdańsku w 2003 r., praca Polska literatura w Szwecji. Dwanaście wykładów.

W latach 90. zainteresowania naukowe A.N. Uggli poszerzyły się o problematykę emigracji polskiej w Szwecji w XX w. Studia nad archiwaliami zebranymi w Archiwum Emigracji Polskiej w Sztokholmie, archiwach szwedzkich i polskich przełożyły się na szereg publikacji poświęconych tym zagadnieniom. Profesor pisał o organizacji studentów polskich w Szwecji, o przyjazdach Polaków do Szwecji po II wojnie światowej i o repatriacji obywateli polskich do kraju w okresie powojennym itd. Zebrany materiał źródłowy, uzupełniony rozmowami z uczestnikami i świadkami tych wydarzeń, pozwolił na opracowanie wyników w postaci dwóch, nieco różniących się od siebie książek. Pierwszą jest monografia Polacy w Szwecji w latach II wojny światowej, która została wydana w języku polskim przez Wydawnictwo Uniwersytetu Gdańskiego w 1996 r. Do napisania tej pracy gorąco zachęcała go żona Margaretha. Drugą, jest jej szwedzkojęzyczna wersja, uzupełniona fragmentami wspomnień i szerszym materiałem ikonograficznym pt. I nordlig hamn: Polacker $i$ Sverige under andra världskriget (W północnym porcie: Polacy w Szwecji podczas II wojny światowej, Uppsala 1997). Interesującą pozycją w dorobku A. N. Uggli jest przetłumaczony i wydany wspólnie z Józefem Lewandowskim fragment pamiętników Svena Grafströma, szwedzkiego dyplomaty, który przebywał w Polsce w chwili wybuchu II wojny światowej: Polskie stronice: dziennik od 5 lipca 1938 do 6 grudnia 1939 roku (Warszawa 1996). Profesor A. N. Uggla był nie tylko badaczem literatury, ale również tłumaczem. Wraz ze swoim przyjacielem, reżyserem, aktorem i historykiem literatury Dagiem Hedmanem przełożył pięć dramatów Witkacego Fem dramer (Pięć dramatów) oraz w 1995 r. Två polska dramatiker. Stanisław Witkiewicz. Stanistaw Wyspiański (Dwóch polskich dramaturgów. Stanisław Witkiewicz. Stanisław Wyspiański), zawierające tłumaczenia i komentarze 
sztuk obu autorów. Tłumaczył i wydał również dramaty Szaniawskiego i komedie Fredry, z myślą o wystawieniu tych sztuk na deskach teatrów szwedzkich.

W 1993 r. A. N. Uggla został pracownikiem Centrum för Multietnisk Forskning (Ośrodek Badań Wielokulturowych) przy Uniwersytecie w Uppsali. Dzięki podjętym staraniom udało mu się stworzyć czasopismo naukowe „Acta Sueco-Polonica” (pierwszy numer ukazał się w 1993 r.), które było wydawane w Uppsali do 2007 r., a następnie przez Instytut Skandynawistyki przy Szkole Wyższej Psychologii Społecznej w Warszawie. Jako redaktor naczelny i wydawca dbał o wysoką wartość zamieszczanych materiałów dotyczących zagadnień językoznawczych, studiów historycznoliterackich, źródeł i recenzji, które były publikowane w języku polskim, szwedzkim lub angielskim.

Olbrzymią rolę przykładał prof. A. N. Uggla do działalności naukowej i popularyzatorskiej. W Uppsali stworzył wraz z J. Lewandowskim seminarium, w którym uczestniczyli polscy i szwedzcy naukowcy. Wojciech Kalinowski wspominał, że seminarium ,spełniało funkcję zarówno naukową jak i, mimo pewnych trudności, towarzyską. Co do tej pierwszej, to często gościliśmy naukowców z Polski — były to pierwsze lata pokomunistyczne, kiedy to nasilały się kontakty między Polską a Szwecją. Sam Andrzej był najbardziej «szwedzki»w tym malutkim polskim środowisku, a jednocześnie był głównym spoiwem grupy, która bez niego na pewno by się rozpadła — wszakże nie brak tam było waśni i konfliktów politycznych związanych z polską polityką i polską historią". Często gościł w Ośrodku Polskich Organizacji Niepodległościowych w Sztokholmie, gdzie przyjeżdżał z wykładami i odczytami na tematy związane ze wspólnymi, polsko-szwedzkimi dziejami. Za popularyzowanie historii Polski w Szwecji i dokonania w tym zakresie został laureatem pierwszej Nagrody Polonii Szwedzkiej „Poloniki” w 2000 r. Blisko współpracował z innymi ośrodkami naukowymi, np. z Katedrą Skandynawistyki Uniwersytetu Gdańskiego, Instytutem Polsko-Skandynawskim w Kopenhadze oraz Szkołą Wyższą Psychologii Społecznej w Warszawie.

Z okazji 60. urodzin przyjaciele Profesora wydali w 2000 r. zbiór artykułów mu poświęconych w tomie Allvarlig debatt och rolig lek (Poważna debata i wesoła zabawa). Książka, zredagowana przez Elżbietę Szweykowską-Olsson, Michała Brona i Lecha Sokoła, zawiera artykuły z dziedziny literatury, filmu, kultury i historii, a więc tych wszystkich dziedzin, które tak bardzo naukowo zajmowały A. N. Ugglę w czasie całej drogi naukowej. Gdy w 2004 r. otrzymał nominację profesorską bibliografia jego prac naukowych liczyła ponad 250 tytułów. Za swoją działalność został odznaczony Złotym Krzyżem Zasługi przez Ryszarda Kaczorowskiego, Prezydenta RP na Uchodźctwie (1989) oraz Krzyżem Oficerskim Orderu Zasługi przez Lecha Wałęsę w Warszawie (1995).

Wspomniany wcześniej W. Kalinowski zapamiętał, że Andrzej Nils Uggla zawsze łagodził i „łatał” skonfliktowanych, natomiast Andrzej Szmilichowski, polski pisarz mieszkający w Szwecji pisał, że Uggla zawsze promieniował życzliwością. Tadeusz Nowakowski planował nakręcenie filmu „o niezwykłej historii związanej z jego rodziną, o jego pasjach i spojrzeniu na świat przez pryzmat polsko-szwedzkiej krwi jaka płynęła w jego żyłach” i dodaje ,był jedną z niewielu osób, której działalność na rzecz polskiego środowiska i popularyzacji spraw polskich w Szwecji, znaczyła tak wiele".

Arnold Kłonczyński (Gdańsk) 